ROZ D Z I A E 5 .

\title{
CZYNNIKI SUKCESU W ZARZĄDZANIU ZMIANAMI W ORGANIZACJACH PUBLICZNYCH NA PRZYKŁADZIE AGENCJI WDRAŻAJĄCEJ POLITYKĘ ROLNĄ
}

\author{
Krzysztof Krukowski ${ }^{1}$
}

\section{Wstęp}

Zarządzanie publiczne jest określane jako zmiana struktury i procesów zachodzących w organizacji publicznej ${ }^{2}$. Zmiany te mogą obejmować przeprojektowanie kluczowych procedur służących obywatelom lub grupie obywateli, ustalenie standardów jakości życia, edukacji lub systemu, w ramach którego pracownicy są rekrutowani, szkoleni, oceniani oraz awansowani. Należy podkreślić, że istotą tych zmian powinno być nakierowane na skuteczność działania tych organizacji ${ }^{3}$. Znaczenie zmiany w zarządzaniu publicznym podkreśla również Jerzy Hausner, które według tego autora koncentruje się na „skutecznym kierowaniu

${ }^{1}$ Dr hab. Krzysztof Krukowski, Uniwersytet Warmińsko-Mazurski w Olsztynie.

${ }^{2}$ C. Pollit, G. Bouckaert, Public Management Reform: A Comparative Analysis, Oxford University Press, New York 2000, s. 8-9.

${ }^{3}$ S.S. Philippidou, K.E. Soderquist, G.P. Prastacos, Towards New Public Management in Greek Public Organizations: Leadership vs. Management, and the Path to Implementation, "Public Organization Review: A Global Journal" 2004, nr 4, s. 320 . 
wieloma i wielokrotnymi zmianami, które - choć niezbędne - nie są ani oczywiste, ani zdeterminowane"4.

Fundamentalne zmiany strukturalne w administracji publicznej zostały zapoczątkowane w drugiej połowie XVIII wieku. Od tego okresu datują się początki politycznych i intelektualnych wydarzeń mających istotny wpływ na zmiany funkcjonowania administracji publicznej, np. Kodeks Napoleona, Rechtsstaat oraz biurokracja, która to w późniejszym okresie została opisana przez Maxa Webera ${ }^{5}$. Koncepcja organizacji biurokratycznej miała m.in. pomóc menedżerom publicznych organizacji w określeniu relacji między zmianami strukturalnymi a wydajnością organizacyjną. Również teoria zarządzania administracyjnego wskazywała, że urzędy działające w warunkach zmian nie mogą sobie pozwolić na utrzymywanie sztywnych opisów ról i łańcuchów zarządzania, chociaż twórcy tej teorii zwracali również uwagę menedżerom publicznym na zalety sprecyzowania zakresu uprawnień i kompetencji każdego urzędnika .

Znaczenie zarządzania zmianami w funkcjonowaniu organizacji publicznych podkreśla się również w koncepcji Nowego Zarządzania Publicznego (NPM), w którym to jednym z podstawowych trendów jest zmiana stylów podejmowania decyzji i współpracy w krajach o ugruntowanej tradycji administracji publicznej ${ }^{7}$. Nowe Zarządzanie Publiczne nie jest spójną tradycyjną teorią organizacji i zarządzania w sektorze publicznym. Jednak w każdym z jej nurtów pojawiają się rozwiązania mające zwiększyć

4 J. Hausner, Zarządzanie publiczne, Wydawnictwo Scholar, Warszawa 2008, s. 41.

${ }^{5}$ J.C.N. Raadschelders, The Use of Models in Administrative History: A Reply to Thuillier, [w:] The Influences of the Napoleonic „Model” of Administration on the Administrative Organization of Other Countries, B. Wunder (red.), International Institute of Administrative Sciences, Working Group: History of Public Administration, Brussels 1995, s. 264; J.R. Tompkins, Organization Theory and Public Management, Thomson\&Wadsworth, Belmont 2005, s. 41.

6 J.R. Tompkins, dz. cyt., s. 122-123.

7 C. Hood, A Public Management for All Seasons?, "Public Administration" 1991, t. 69 , s. 3 . 
efektywność funkcjonowania organizacji publicznych w oparciu o zmiany w praktyce ich funkcjonowania.

Na bazie krytyki koncepcji związanych z NPM oraz tradycyjnego zarządzania publicznego powstała teoria oparta na nowym ładzie publicznym zwanym New Public Governance (NPG). Niektórzy autorzy good governance tłumaczą jako dobre rządzenie ${ }^{8}$. Autorzy tej koncepcji podkreślają również otwartość organizacji publicznych na zmiany ${ }^{9}$. Modelem funkcjonowania organizacji opartym na ogólnym nurcie zarządzania zmianami w organizacjach publicznych jest New Business Models for Public-Sector Innovation ${ }^{10}$. Podkreśla się w nim zachęcanie menadżerów publicznych do większego nacisku na wymierne korzyści dla obywateli przez udoskonalenia i zmiany w świadczeniu usług publicznych. Niektórzy autorzy podkreślają, że pozwala to pokonać opór organizacyjny wobec zmiany, a również awersję menadżerów publicznych do ryzyka ${ }^{11}$.

W przypadku organizacji publicznych o znaczeniu zarządzania zmianami decyduje również jej otoczenie. Wpływ otoczenia na funkcjonowanie organizacji publicznych wynika z powstawania innowacji technicznych i technologicznych w procesie świadczenia usług, występowania częstych i nieprzewidywalnych zmian w polityce państwa oraz zmiana w postawach i wartościach obywateli. Ponadto organizacje publiczne rzadziej wprowadzają zmiany, ze względu na fakt, że oferowane usługi nie ulegają zmianom w długim okresie oraz nie pojawiają się nowi konkurenci.

${ }^{8}$ B. Jessop, Promowanie „dobrego rządzenia” i ukrywanie jego słabości: refleksja nad politycznymi paradygmatami i politycznymi narracjami $w$ sferze rządzenia, „Zarządzanie Publiczne" 2007, nr 2(2), s. 5-25.

${ }^{9}$ K. Raczkowski, W. Mikułowski, Specyfika i zakres definiowania zarządzania publicznego, „Przedsiębiorczość i Zarządzanie” 2013, t. XIV, z. 13, cz. III, s. 15.

${ }^{10}$ P. Micheli, M. Schoeman, D. Baxter, K. Goffin, New Business Models for Public-Sector Innovation. Successful Technological Innovation for Government, "Research-Technology Management" 2012, September-October, s. 425-432.

${ }^{11}$ K. Brown, N. Ryan, R. Parker, New modes of service delivery in the public sector: Commercialising government services, "International Journal of Public Sector Management" 2002, t. 13, nr 2, s. 206-221. 
Istotnym obszarem związanym z zarządzaniem zmianami w organizacji publicznej jest wdrażanie w nich rozwiązań opartych na procesach. Szczególny wpływ na to ma wprowadzanie w administracji publicznej coraz bardziej skomplikowanych rozwiązań informatycznych. Celem zmian w administracji publicznej opartej na podejściu procesowym są wewnętrzne wyzwania, wynikające z nieefektywnych, funkcjonalnych struktur organizacyjnych oraz chęć poprawy jakości świadczonych usług.

Podsumowując można stwierdzić, że zmiana oraz zarządzanie zmianą są istotnymi elementami w większości koncepcji zarządzania publicznego. Dlatego też, ważne jest zidentyfikowanie kluczowych czynników decydujących o wprowadzaniu z sukcesem zmian w organizacjach publicznych, w tym agencjach rządowych.

Celem rozdziału jest zidentyfikowanie kluczowych czynników sukcesu w zarządzaniu zmianami w agencji rządowej wdrażającej politykę rolną. W ramach realizacji celu w warstwie teoretycznej przeprowadzono analizę literatury z zakresu zarządzania zmianą w organizacjach publicznych. W warstwie empirycznej przedstawiono wyniki badań ankietowych przeprowadzonych w jednym z oddziałów regionalnych agencji rolnej. Przeprowadzono je w październiku 2019 roku na grupie 51 pracowników.

\subsection{Specyfika zmian w organizacjach publicznych}

Zarządzanie zmianami w organizacjach publicznych wynika bardzo często z odgórnych strategii sprawowania władzy politycznej ${ }^{12}$. Można uznać to za czynnik mający znaczenie strategiczne w funkcjonowaniu organizacji. Zmiany osiągane są poprzez wstępnie zaprojektowany odgórny proces wdrażania wynikający z nowej strategii ${ }^{13}$. Literatura przedmiotu na

${ }^{12}$ E. Ferlie, L. Ashburner, L. Fitzgerald, A.M. Pettigrew, The New Public Management In Action, Oxford University Press, Oxford 1996.

${ }^{13}$ D.C. Dunphy, Embracing the paradox: Top-down versus participative management of organizational change: a commentary on Conger and Bennis, [w:] Breaking The 
temat zarządzania zmianami w sektorze publicznym wskazuje na większą złożoność i niejednoznaczność tego procesu w organizacjach publicznych, niż w biznesowych. Podkreśla się również znaczenie otoczenia w tym procesie $^{14} \cdot \mathrm{Z}$ analizy literatury wynika, że określone cechy organizacji sektora publicznego wpływają na zmiany i zarządzanie nimi ${ }^{15}$. Jednym z obszarów wyróżniającym wprowadzanie zmian jest centralizacja zarządzania organizacją publiczną. Z centralizacji wynika m.in. niemożność podejmowania decyzji bez zatwierdzenia przez przełożonego ${ }^{16}$. Ogranicza to w znaczny sposób swobodę wdrażania zmian, nawet tych mało istotnych. Drugim z obszarów mającym wpływ na kontekst wprowadzania zmian jest wysoka formalizacja działań. Wynika to z biurokratycznego charakteru organizacji publicznej. Przy zarządzaniu zmianami w organizacjach publicznych należy również zwrócić uwagę, że dochodzi w nich do konfliktów politycznych w wyniku sprzecznych lub niejednoznacznie zdefiniowanych celów.

Do zidentyfikowania cech związanych z procesami zmian i ich wdrażaniem w organizacjach publicznych mogą być wykorzystywane następujące obszary: kontekst, treść, proces, wyniki i przywództwo ${ }^{17}$. Kontekst jako cecha wyróżniająca zarządzanie zmianami w organizacjach publicznych, odnosi się do ich środowiska wewnętrznego i zewnętrznego (otoczenia). Szczególne znaczenie w procesie zarządzania zmianą posiada otoczenie

Code of Change, M. Beer, N. Nohria (red.), Harvard Business School Press, Boston 2000, s. 123-136.

${ }^{14}$ C.E. Lutrin, A.B. Shani, Reinventing in the Public Sector: Some Lessons and Limits, [w:] Accountability and Radical Change in Public Organizations, R.R. Sims (red.), Quorum Books, Westport, CT 1998, s. 71-96.

${ }^{15}$ K.R. Isett, S.A. Glied, M.S. Sparer, L.D. Brown, When change becomes transformation: A case study of change management in Medicaid offices in New York City, "Public Management Review" 2012, nr 15(1), s. 1-17.

${ }^{16} \mathrm{~J}$. Van der Voet, The effectiveness and specificity of change management in a public organization: Transformational leadership and a bureaucratic organizational structure, "European Management Journal" 2014, nr 32(3), s. 373-381.

${ }^{17}$ B.S. Kuipers i in., The management of change in public organizations: A literature review, "Public Administration" 2014, nr 92(1), s. 11-12. 
polityczne, ponieważ menadżerowie publiczni odpowiadają pośrednio lub bezpośrednio przed organami władzy publicznej. Do pozostałych, podstawowych elementów otoczenia warunkujących funkcjonowanie podmiotów sektora publicznego można zaliczyć: warunki technologiczne, warunki ekonomiczne, demograficzne cechy społeczeństwa, warunki ekologiczne czy też kulturowe ${ }^{18}$. Kontekst wewnętrzny wynika z faktu, że organizacje publiczne i biznesowe różnią się celami, jak również ich skutecznością i efektywnością realizacji ${ }^{19}$. Treść zmian odnosi się do tego, co się zmieniło w organizacji. Typowe zmiany dotyczą wprowadzania w organizacjach publicznych nowych procesów, systemów i procedur (np. wprowadzenie nowych systemów księgowych, mierników wydajności, technologii informatycznych (IT)). Treść zmian odnosi się również do aspektów związanych z zarządzaniem zasobami ludzkimi, innowacjami ${ }^{20}$ oraz reorganizacją ${ }^{21}$. Proces zmian w organizacjach publicznych może przebiegać zgodnie z linearną progresją przez kolejne etapy. Na przykład zgodnie z zaproponowanym przez J.P. Kottera ${ }^{22}$ ośmioetapowym modelem procesu wprowadzania zmian. Proces ten jednak rzadko, w praktyce, przebiega w tak prosty, liniowy sposób ${ }^{23}$. Kolejną cechą są wyniki zmian, które należy postrzegać jako merytoryczne rezultaty wdrożenia zmiany, które mogą być zamierzone lub niezamierzone, pozytywne lub negatywne. W organizacjach publicznych podkreśla się również często znaczenie wartości jako wyniku zmian ${ }^{24}$. Następnym czynnikiem jest przywództwo

${ }^{18}$ H.G. Rainey, Understanding and Managing Public Organizations, John Wiley \& Sons, San Francisco 2009, s. 91.

${ }^{19}$ E.M. Berman, Performance and productivity in public and nonprofit organizations, M.E. Sharpe Armonk, New York-London 2006, s. 7-9.

20 S. Borins, Leadership and Innovation in the Public Sector, "Leadership \& Organization Development Journal" 2002, nr 23 (8), s. 467.

${ }^{21}$ G.A. Boyne, Strategies for Public Service Turnaround: Lessons From the Private Sector?, „Administration \& Society” 2006, nr 38 (3), s. 379-380.

22 J.P. Kotter, Leading Change, Harvard Business School Press, Boston 1996, s. 21.

23 J. Amis, T. Slack, C.R. Hinings, The Pace, Sequence, and Linearity of Radical Change, "Academy of Management Journal" 2004, nr 47 (1), s. 16.

${ }^{24}$ B.S. Kuipers i in., dz. cyt., s. 1-20. 
jako fakt mający wpływ na zarządzanie zmianą ${ }^{25}$. W literaturze można spotkać różne poglądy na przywództwo organizacji publicznych, charakterystyczne dla zarządzania zmianami. Jeden z tych podziałów dotyczy przywództwa transformacyjnego oraz przedsiębiorczego ${ }^{26}$. W pierwszym ujęciu wynikającym z pojęcia zmiany działania przywódcy skupiają się na tworzeniu zmian oraz kultury w organizacji. Cechy, którymi charakteryzują się przywódcy transformacyjni, a które mogą mieć wpływ na procesy zarządzania zmianami, są zorientowane na osiąganie długoterminowych celów oraz działanie etyczne. W drugim przypadku przywództwo opiera się na idei innowacyjności i wyjścia naprzeciwko oczekiwaniom interesariuszy. Przywódcy przedsiębiorczy w organizacjach publicznych charakteryzują się cechami, takimi jak: wyjątkowa osobowość, zmysł polityczny, zmysł do zdobywania zwolenników. Uznawani są oni za agentów radykalnych zmian w organizacjach publicznych ${ }^{27}$. Obszar przywództwa $\mathrm{w}$ procesie zarządzania zmianami może stanowić jedno z ważniejszych źródeł sukcesu we wdrażaniu zmian w podmiotach publicznych.

\subsection{Czynniki sukcesu we wdrażaniu zmian w organizacjach publicznych}

W literaturze przedmiotu można spotkać wyniki badań, w których zidentyfikowane zostały czynniki sukcesu w zarządzaniu zmianami w organizacjach publicznych. Dotyczą one w większości wszystkich obszarów funkcjonowania organizacji. Druga grupa badań przedstawiana w literaturze dotyczy tylko wybranych obszarów zarządzania w organizacjach

${ }^{25}$ M. Higgs, D. Rowland, All Changes Great and Small: Exploring Approaches to Change and Its Leadership, "Journal of Change Management" 2005, nr 5(2), s. 126128.

${ }^{26}$ A. Austen-Tynda, Przywództwo $w$ organizacjach publicznych, [w:] Zarządzanie publiczne - elementy teorii i praktyki, A. Frączkiewicz-Wronka (red.), Wydawnictwo Akademii Ekonomicznej, Katowice 2009, s. 252-254.

${ }^{27}$ Tamże, s. 255. 
publicznych oraz ukazuje wpływ konkretnych czynników na wprowadzanie zmian.

Całościową analizę czynników sukcesu zarządzania zmianami organizacyjnymi w sektorze publicznym przedstawili w swoich badaniach S. Fernandez i H.G. Rainey ${ }^{28}$. Wskazali oni osiem kluczowych czynników. Według tych autorów jest to swoisty plan działania dla menedżerów publicznych, którzy wprowadzają zmiany. Czynniki te obejmują:

- Informowanie o potrzebie zmian - badania wskazują, że wdrożenie planowanych zmian wymaga, aby liderzy weryfikowali potrzebę zmian i aby przekonali innych członków organizacji oraz interesariuszy zewnętrznych do konieczności ich wprowadzenia. Proces przekonywania jednostek o potrzebie zmiany często zaczyna się od stworzenia wizji. Pomyślne wdrożenie nowych programów zależy również od umiejętności kierownictwa najwyższego szczebla do rozpowszechniania informacji o zmianie i przekonaniu pracowników o pilności zmian. Przykładowo R. Denhardt i J. Denhardt ${ }^{29}$ opisują, w jaki sposób efektywni menedżerowie samorządowi weryfikują potrzebę zmian poprzez „słuchanie i uczenie się", a następnie komunikują te potrzeby w sposób budujący wsparcie dla zmian.

- Zaplanowanie zmian - w organizacji musi być opracowany plan wprowadzania zmian. Wykorzystywany jest on jako mapa drogowa organizacji, określająca kierunek dotarcia do preferowanego stanu końcowego. Plan ten powinien zawierać zidentyfikowane przeszkody i środki służące pokonywaniu tych przeszkód.

- Zbudowanie wewnętrznego wsparcia na rzecz zmian i przezwyciężenia oporu - menadżerowie muszą zbudować wewnętrzny system wsparcia

28 S. Fernandez, H.G. Rainey, Managing Successful Organizational Change in the Public Sector, "Public Administration Review" 2006, March-April, s. 169-174.

${ }^{29}$ R.B. Denhardt, J.V. Denhardt, Leadership for Change: Case Studies in American Local Government, IBM Center for the Business of Government, Washington, DC 1999. 
dla zmian. Zmniejszenie oporu pracowników wobec zmian powinno odbywać się przez ich powszechny udział w procesie zmian.

- Zapewnienie wsparcia i zaangażowania najwyższego kierownictwa wsparcie i zaangażowanie naczelnego kierownictwa w zmianie odgrywa szczególnie istotną rolę w sukcesie zmian.

- Wsparcie zewnętrzne zmian - menadżerowie publiczni muszą rozwijać wsparcie ze strony polityków oraz kluczowych interesariuszy zewnętrznych. Wpływ tych podmiotów na rezultat zmian wynika częściowo z ich zdolności do wprowadzania ustawowych zmian i kontrolowania przepływu ważnych zasobów do organizacji.

- Zapewnienie zasobów - zmiana wymaga posiadania wystarczających zasobów. Planowanie zmiany organizacyjnej wiąże się z przesunięciem lub przekierowaniem ograniczonych zasobów organizacyjnych. Brak zapewnienia odpowiednich zasobów wspierających planowaną zmianę prowadzi do słabych efektów wdrożenia, wyższych poziomów stresu interpersonalnego, a nawet zaniedbania podstawowych działań i funkcji organizacyjnych.

- Zinstytucjonalizowanie zmiany - aby zmiana była trwała, członkowie organizacji muszą włączyć nowe zasady do swoich codziennych zajęć. Pracownicy muszą uczyć się i rutynizować te zachowania w krótkim czasie, a liderzy muszą zinstytucjonalizować je na trwałe, aby nowe wzorce zachowania wypierały stare.

- Wprowadzanie zmian w systemach organizacji - menadżerowie publiczni muszą zapewnić kompleksowe podejście do zmian, integrując je z pozostałymi podsystemami organizacji. Zmiana tylko jednego lub dwóch podsystemów nie wygeneruje wystarczającej siły, aby spowodować zmianę organizacyjną. W literaturze można spotkać się z poglądem, że wdrożenie wielu zmian, bez zrozumienia struktury i charakteru połączeń między podsystemami, może skutkować dodatkowymi kosztami i dłuższym okresem wdrożenia ${ }^{30}$.

${ }^{30}$ M.T. Hannan, L. Polos, G.R. Carroll, The Fog of Change: Opacity and Asperity in Organizations, “Administrative Science Quarterly" 2003, nr 48 (3), s. 399-432. 
Podobnie kluczowe czynniki sukcesu we wdrażaniu zmian w organizacji zdefiniował W.J. Kikert ${ }^{31}$. Dokonał on kompilacji czynników wskazanych w badaniach S. Fernandez i H.G. Rainey ${ }^{32}$ dla organizacji publicznej oraz J. Kottera ${ }^{33}$, opracowanych dla organizacji biznesowych. Według W.J. Kikerta ${ }^{34}$ do czynników sukcesu należy zaliczyć:

1. Stworzenie poczucia pilności zmiany, zapewnienie potrzeb zmian, zbudowanie wsparcia wewnętrznego.

2. Opracowanie i przedstawienie wizji i strategii zmian.

3. Komunikowanie zmian, upoważnienie pracowników do działania.

4. Zapewnienie wsparcia i zaangażowania najwyższego kierownictwa.

5. Budowanie wsparcia zewnętrznego.

6. Zapewnienie odpowiednich zasobów.

7. Zinstytucjonalizowanie zmian oraz ich zakotwiczenie w kulturze organizacyjnej.

8. Dążenie do kompleksowej zmiany.

Jennifer Stewart oraz Paul Kringas ${ }^{35}$, na podstawie badań australijskich organizacji publicznych, zidentyfikowali czynniki sukcesu w zakresie skutecznego wdrażania zmian. Według tych autorów zależy on od wielu czynników: posiadania wypracowanego modelu wprowadzenia zmiany; efektywnego przywództwa; posiadania wystarczających zasobów; komunikacji w organizacji; stopnia, w jakim zmiana została wynegocjowana; wsparcia politycznego oraz wsparcia dla zmiany interesariuszy zewnętrznych.

${ }^{31}$ W.J. Kickert, Specificity of change management in public organizations: Conditions for successful organizational change in Dutch ministerial departments, "The American Review of Public Administration" 2014, nr 44(6), s. 693-717.

32 S. Fernandez, H.G. Rainey, dz. cyt., s. 169-174.

33 J. Kotter, The heart of change, Harvard Business School Press, Boston 2002.

${ }^{34}$ W.J. Kickert, dz. cyt., s. 693-717.

35 J. Stewart, P. Kringas, Change Management - Strategy and Values in Six Agencies from the Australian Public Service, "Public Administration Review" 2003, t. 63, nr 6, s. 686 . 
David Baker ${ }^{36}$ wskazuje, że istotnym elementem mającym wpływ na zarządzanie w organizacjach publicznych jest posiadanie przez menadżerów świadomości specyfiki wewnętrznej organizacji. Według tego autora sprawny menadżer powinien skupić się w procesie zmian na ${ }^{37}$ :

- upewnieniu się, że wszyscy pracownicy dodają wartości w procesie zmian;

- zapewnieniu, żeby pracownicy czuli się zaangażowani, zintegrowani i wartościowi;

- zbudowaniu grupy mającej ten sam cel;

- upewnieniu się, że menedżerowie mają właściwe umiejętności zarządzania pracownikami;

- znalezieniu właściwej równowagi pomiędzy ryzykiem a sensem wprowadzania zmian;

- poprawieniu wewnętrznej reputacji organizacji.

W badaniach zawartych w literaturze z zakresu zarządzania zmianą w organizacji publicznej podkreśla się również znaczenie pojedynczych czynników pozwalających osiągnąć sukces w zarządzaniu zmianą. Najczęściej spotkać można badania dotyczące roli przywództwa (liderów)

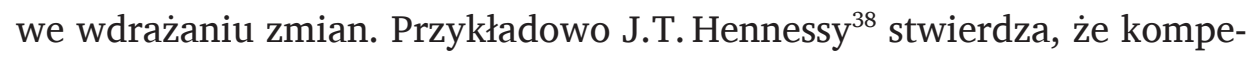
tencje posiadane przez liderów są skorelowane ze stopniem zmian kulturowych zachodzących w organizacjach publicznych. Takie same wyniki przedstawili I.-H. Kester i Ch. Paintera ${ }^{39}$, którzy prowadzili badania wśród brytyjskich samorządowców. W innych badaniach stwierdzono, że organizacja publiczna będzie łatwo tworzyć, wdrażać i podtrzymywać zmiany w wybranych obszarach pracy, jeśli przywództwo organizacyjne

${ }^{36}$ D. Baker, Strategic change management in public sector organizations, Elsevier, Oxford 2007, s. 231.

37 Tamże.

38 J.T. Hennessy, Jr., Reinventing Government: Does Leadership Make a Difference?, "Public Administration Review" 1998, nr 58(6), s. 522-532.

${ }^{39}$ I-H. Kester, Ch. Painter, The Management Challenge in Local Government Emerging Themes and Trends, "Local Government Studies" 1991, nr 17(3), s. 69-90. 
będzie silne ${ }^{40}$. Według wyników tych badań jest ono mocno skorelowane z sukcesem programu zmian. Dlatego też ważne jest, aby przywódcza rola bezpośrednich przełożonych nie została przeoczona podczas zmian w organizacjach publicznych ${ }^{41}$.

Istnieje kilka kluczowych umiejętności, które muszą posiadać (lub nabyć) i używać menadżerowie publiczni w celu skutecznego zarządzania zmianą ${ }^{42}$ :

- umiejętności polityczne, aby radzić sobie z ludźmi i kulturami;

- umiejętności analityczne, aby dostarczyć logiczne i racjonalne argumenty, które nie mogą być kwestionowane w rzeczywistości;

- umiejętności międzyludzkie, aby zapewnić odpowiednią komunikację i empatię;

- umiejętność radzenia sobie z ogromną różnorodnością interakcji międzyludzkich;

- umiejętności rozumienia systemów organizacyjnych i sposobów radzenia sobie z nimi;

- umiejętności biznesowe, aby zrozumieć, jak organizacja przechodząca zmiany - faktycznie działa.

Również badania Bita A. Kash ${ }^{43}$ wskazują, że przywództwo jest ważnym czynnikiem sukcesu we wprowadzaniu zmian. Zauważono także, że liderzy sektora publicznego mogą korzystać z mandatów politycznych i zewnętrznych możliwości wpływów, aby zweryfikować i zakomunikować potrzebę zmian ${ }^{44}$.

40 J. Stewart, P. Kringas, dz. cyt., s. 675-688.

41 J. Van der Voet, dz. cyt., s. 381.

42 D. Baker, dz. cyt., s. 243.

${ }^{43}$ B.A. Kash, Success Factors for Strategic Change Initiatives: A Qualitative Study of Healthcare Administrators' Perspectives, "Journal of Healthcare Management" 2014, nr 59(1), s. 65-81.

${ }^{4}$ A.M. Abramson, P.R. Lawrence, The Challenge of Transforming Organizations: Lessons Learned about Revitalizing Organizations, [w:] Transforming Organizations, 
Kolejnym ważnym czynnikiem zmian w sektorze publicznym jest udział pracowników w realizacji programu zmian. Abdullah Alhaqbani ${ }^{45}$ sugeruje, że pracownicy powinni mieć możliwość uczestniczenia $\mathrm{w}$ procesie decyzyjnym w celu wprowadzenia zmian, ponieważ pomaga to $\mathrm{w}$ uniknięciu oporu z ich strony. Niektóre badania podkreślają, że kluczowym warunkiem sukcesu zmian w organizacji jest gotowość pracowników do ich wdrożenia ${ }^{46}$. W celu włączenia pracowników w proces zmian można organizować szkolenia z tego zakresu. Szkolenia są również wskazywane jako czynnik sukcesu we wprowadzaniu zmian w sektorze publicznym $^{47}$.

Niektóre badania z zakresu zarządzania zmianą w organizacjach publicznych wskazują na znaczenie posiadanych przez organizację zasobów. Wymienia się je jako czynnik sukcesu szczególnie w obszarze zmian związanych z poprawą świadczenia usług publicznych ${ }^{48}$. W obszarze zmian związanych z doskonaleniem usług w organizacjach publicznych wskazuje się również na znaczenie wykorzystania innowacyjnej i zdigitalizowanej technologii, jako czynnika sukcesu ${ }^{49}$. Do grupy czynników związanych z wprowadzaniem zmian w usługach publicznych zalicza się również uwolnienie procedur i ograniczenie kontroli biurokratycznych ${ }^{50}$.

M.A. Abramson, P.R. Lawrence (red.), Rowman \& Littlefield Lanham, MD 2001, s. $1-10$.

${ }^{45}$ A. Alhaqbani, Impact of key organisational factors in facilitating TQM in a Saudi Arabian public sector organisation: An empirical study, "International Journal of Innovations in Business" 2013, t. 2, nr 8, s. 733.

${ }^{46}$ M. Higgs, D. Rowland, dz. cyt., s. 121-151.

${ }^{47}$ B.A. Kash, dz. cyt., s. 65-81.

${ }^{48}$ G.A. Boyne, Sources of Public Service Improvement: A Critical Review and Research Agenda, "Journal of Public Administration Research and Theory" 2003, nr 13(3), s. 367-394.

${ }^{49}$ T. A. el Badawy, S.A. Attia, The Effect of Change Management on E-Government: Implementation in Egypt, "The International Journal Of Business \& Management" 2014, t. 2, nr 9, s. 141.

50 J.R. Thompson, Devising Administrative Reform that Works: The Example of the Reinvention Lab Program, "Public Administration Review" 1999, nr 59(4), s. 283-292. 
Duże znaczenie we wprowadzaniu zmian organizacyjnych przypisuje się kulturze organizacyjnej ${ }^{51}$. Uznanie kultury organizacyjnej w procesach zmian jest ważne, ponieważ określa ona parametry dla zmian organizacyjnych, ale także może być sama przedmiotem zmiany. Dotyczy to w szczególności wysiłków na rzecz zwiększenia świadczenia usług publicznych nastawionych na obywatela ${ }^{52}$.

W literaturze podkreśla się również znaczenie w procesie wprowadzenia zmian roli „agenta zmian”53. Znaczenie agentów zmian powiązane jest w organizacjach publicznych z przywództwem. W przypadku przywództwa przedsiębiorczego podkreśla się, że stosuje ono zaawansowane techniki zarządzania umożliwiające wprowadzanie radykalnych zmian $^{54}$. Agenci zmian mogą mieć wpływ na zmniejszenie ograniczenia lub presji związanych z procesem zarządzania zmianami, które pozostają poza kontrolą menedżerów publicznych. Przykładowo, przywódcy transformacyjni mają wpływ na proces zarządzania zmianą poprzez umiejętności angażowania zwolenników oraz tworzenia więzi między nimi, które w konsekwencji mogą prowadzić do zwiększenia motywacji oraz koncentrowania się na celach grupowych ${ }^{55}$. W literaturze podkreśla się również rolę środowiska organizacji w ustalaniu parametrów zmiany, które może być reprezentowane przez agentów zmian. Środowisko organizacji publicznych pozostaje bardzo często pod wpływem polityki. I dlatego posiadanie (lub brak) politycznego poparcia dla zmian jest kluczowym czynnikiem ${ }^{56}$. Nadzór polityczny nad organizacją może wpły-

${ }^{51}$ M. Beer, R.A. Eisenstat, B. Spector, Why Change Programs Don't Produce Change, "Harvard Business Review" 1990, nr 68(6), s. 158-166.

${ }^{52}$ K. Junge J. Kelleher, K. Hadjivassiliou, Think Paper 1: What is the scope for organizational change in the public sector in Europe? Version No. 5.0, The Tavistock Institute, London 2006, s. 11.

53 J. Stewart, P. Kringas, dz. cyt., s. 684.

${ }^{54}$ A. Austen-Tynda, dz. cyt., s. 255.

55 Tamże, s. 253-254.

${ }^{56}$ D.H. Rosenbloom, Have an Administrative Rx? Don't Forget the Politics!, "Public Administration Review" 1993, nr 53(6), s. 503-508. 
wać na wynik planowanych zmian, tworząc i przekazując wizję, która wyjaśnia ich potrzebę.

\subsection{Ocena czynników sukcesu w zarządzaniu zmianą w badanej instytucji}

Badania ankietowe zostały przeprowadzone w październiku 2019. Kwestionariusz ankiety skierowany był do pracowników jednego z oddziałów regionalnych agencji rolnej. Uzyskano 51 poprawnie wypełnionych kwestionariuszy, w których respondenci wskazali czynniki, które są w ich opinii, istotne we wdrażaniu zmian w ich organizacji. Do oceny czynników zastosowano skalę Likerta, w której wartości 1 przypisano czynnikom nieistotnym, a wartości 5 czynnikom bardzo istotnym.

Wśród respondentów przeważały osoby z wykształceniem wyższym, w tym najwięcej posiadało wykształcenie o profilu technicznym - 34 osoby (tabela 5.1.). Tylko 3 osoby wśród badanych zajmowały stanowisko kierownicze. Największą grupę pracowników reprezentowały osoby ze stażem od 6 do 10 lat (18 osób). Istotną grupą pod względem wieku były również osoby ze stażem powyżej 20 lat.

Tabela 5.1. Charakterystyka badanej próby (w osobach)

\begin{tabular}{|c|c|c|c|}
\hline \multicolumn{4}{|c|}{ Wykształcenie } \\
\hline średnie & $\begin{array}{c}\text { wyższe } \\
\text { techniczne }\end{array}$ & $\begin{array}{c}\text { wyższe } \\
\text { humanistyczne }\end{array}$ & $\begin{array}{c}\text { wyższe } \\
\text { społeczne }\end{array}$ \\
\hline 2 & 34 & 9 & 6 \\
\hline \multicolumn{4}{|c|}{ Stanowisko } \\
\hline \multicolumn{2}{|c|}{ kierownicze } & \multicolumn{2}{|c|}{ niekierownicze } \\
\hline \multicolumn{2}{|c|}{3} & \multicolumn{2}{|c|}{48} \\
\hline
\end{tabular}




\begin{tabular}{|c|c|c|c|}
\hline \multicolumn{4}{|c|}{ Staż pracy (w latach) } \\
\hline$<5$ & od 6 do 10 & od 11 do 20 & $<20$ \\
\hline 9 & 18 & 8 & 16 \\
\hline \multicolumn{4}{|c|}{ Płeć } \\
\hline \multicolumn{2}{|c|}{ mężczyzna } & \multicolumn{2}{|c|}{ kobieta } \\
\hline \multicolumn{2}{|c|}{27} & \multicolumn{2}{|c|}{24} \\
\hline \multicolumn{4}{|c|}{$\begin{array}{c}\text { Mam kwalifikacje na poziomie kursu (szkolenia, studia podyplomowe) } \\
\text { w zakresie zarządzania zmianą }\end{array}$} \\
\hline \multicolumn{2}{|c|}{ tak } & \multicolumn{2}{|c|}{ nie } \\
\hline \multicolumn{2}{|c|}{13} & \multicolumn{2}{|c|}{38} \\
\hline
\end{tabular}

Implementacja zmian jest kluczowym elementem mojej funkcji w organizacji

\begin{tabular}{cc}
\hline tak & nie \\
\hline 16 & 35 \\
\hline
\end{tabular}

Źródło: opracowanie własne.

Wpływ na postrzeganie czynników istotnych we wdrażaniu zmian może mieć posiadanie kwalifikacji z zakresu zarządzania zmianą. Wśród pracowników badanej organizacji przeważały osoby nieposiadające takich kwalifikacji (38 osób). Podobnie jest w przypadku funkcji pracowników w organizacji związanej z wdrażaniem zmian. Tylko dla 16 osób implementacja zmian jest kluczowym elementem pełnionej przez nich funkcji w organizacji. Jednak jak wynika z uzyskanych efektów, wszyscy respondenci byli uczestnikami wprowadzania zmian w swojej organizacji (tabela 5.2.).

Największa liczba pracowników uczestniczyła w zmianach wynikających z pojawienia się nowego przełożonego (kierownika lub dyrektora) (45 osób). Również większość badanych było uczestnikiem zmian wywo- 
łanych $\mathrm{w}$ związku z redukcją zatrudnienia lub znaczącym wzrostem zatrudnienia (43 osoby). Tylko dwie osoby były uczestnikami wprowadzania systemów zarządzania jakością. Brały one udział w tych zmianach poza badaną instytucją.

Tabela 5.2. Uczestnictwo badanych pracowników we wprowadzaniu zmian w organizacji (w osobach)

\begin{tabular}{lcc}
\hline Wyszczególnienie & tak & nie \\
\hline \hline $\begin{array}{l}\text { przeprojektowanie procesu (procedur) lub ulepszenie procesu } \\
\text { (procedur) }\end{array}$ & 29 & 22 \\
\hline $\begin{array}{l}\text { zmiany w zatrudnieniu (redukcja zatrudnienia/znaczące } \\
\text { zwiększenie zatrudnienia) }\end{array}$ & 43 & 8 \\
\hline $\begin{array}{l}\text { wprowadzenie pracy w zespołach zadaniowych/projektowych } \\
\text { wprowadzanie kompleksowego zarządzanie jakością, np. norm ISO }\end{array}$ & 2 & 49 \\
\hline $\begin{array}{l}\text { wprowadzenie wymogu posiadania nowych umiejętności/wiedzy } \\
\text { przez pracowników }\end{array}$ & 28 & 23 \\
\hline zmiana kultury organizacyjnej & 17 & 34 \\
\hline zmiana kierownika/dyrektora & 45 & 6 \\
\hline delegowanie uprawnień pracownikom niebędącym menedżerami & 30 & 21 \\
\hline zmiany w pracy komórek organizacyjnych & 39 & 12 \\
\hline
\end{tabular}

Źródło: opracowanie własne.

Mnogość zmian, w których uczestniczyli pracownicy badanej instytucji oraz relatywnie długi okres ich zatrudnienia w organizacji pozwala na stwierdzenie, że są oni w stanie wskazać i ocenić czynniki, które - ich zdaniem - mają największe znaczenie w sukcesie wprowadzania zmian $\mathrm{w}$ badanej organizacji.

Na podstawie analizy literatury zidentyfikowano 13 czynników, które mają wpływ na osiągnięcie sukcesu we wdrażaniu zmian w organizacjach 
publicznych. Respondenci dokonali takiej oceny w zależności od ich istotności w zarządzaniu zmianami w ich konkretnej organizacji (tabela 5.3.).

Tabela 5.3. Ocena czynników sukcesu we wdrażaniu zmian w agencji rolnej

\begin{tabular}{|c|c|c|c|c|c|}
\hline \multirow{2}{*}{ Wyszczególnienie } & \multicolumn{5}{|c|}{ Ocena (w \% wskazań) } \\
\hline & 1 & 2 & 3 & 4 & 5 \\
\hline $\begin{array}{l}\text { ustanowienie poczucia pilności (potrzeby) } \\
\text { zmian }\end{array}$ & 0,0 & 9,8 & 15,7 & 47,1 & 27,5 \\
\hline $\begin{array}{l}\text { opracowanie planu wprowadzenia zmian } \\
\text { (wizji, strategii) }\end{array}$ & 0,0 & 0,0 & 3,9 & 19,6 & 76,5 \\
\hline opracowanie modelu wprowadzenia zmian & 0,0 & 0,0 & 7,8 & 45,1 & 47,1 \\
\hline komunikacja w organizacji & 0,0 & 0,0 & 0,0 & 45,1 & 54,9 \\
\hline posiadanie wystarczających zasobów & 0,0 & 0,0 & 0,0 & 27,5 & 72,5 \\
\hline silne przywództwo lidera & 3,9 & 0,0 & 11,8 & 60,8 & 23,5 \\
\hline zmotywowanie pracowników do zmian & 0,0 & 0,0 & 0,0 & 27,5 & 72,5 \\
\hline $\begin{array}{l}\text { zakotwiczenie wyniku zmian w kulturze } \\
\text { organizacyjnej }\end{array}$ & 5,9 & 0,0 & 21,6 & 54,9 & 17,6 \\
\hline posiadanie wsparcia politycznego do zmian & 37,3 & 7,8 & 29,4 & 21,6 & 3,9 \\
\hline wprowadzenie agenta zmian & 19,6 & 11,8 & 41,2 & 27,5 & 0,0 \\
\hline $\begin{array}{l}\text { wprowadzanie innowacyjnej } \\
\text { i zdigitalizowanej technologii }\end{array}$ & 15,7 & 3,9 & 25,5 & 39,2 & 15,7 \\
\hline $\begin{array}{l}\text { uwolnienie procedur i ograniczenie kontroli } \\
\text { biurokratycznych }\end{array}$ & 11,8 & 9,8 & 11,8 & 41,2 & 25,5 \\
\hline $\begin{array}{l}\text { znalezienie właściwej równowagi między } \\
\text { ryzykiem a sensem wprowadzania zmian }\end{array}$ & 11,8 & 3,9 & 17,6 & 45,1 & 21,6 \\
\hline
\end{tabular}

Źródło: opracowanie własne.

Rozkład odpowiedzi punktowej wskazuje, że najwięcej ocen świadczących o niskiej istotności (oceny 1 oraz 2) we wdrażaniu zmian uzyskały: 
posiadanie wsparcia politycznego do zmian (45,1\% wskazań na ocenę 1 lub 2), wprowadzenie agenta zmian $(31,4 \%)$ i ograniczenie kontroli biurokratycznych i uwolnienie procedur (21,6\%). Szczególnie interesujące jest wskazanie jako mało istotnego posiadanie wsparcia politycznego. Z wyników badań prezentowanych w literaturze czynnik ten jest uważany za bardzo istotny. Na jego istotność wskazali w swoich badaniach Walter J. Kikerta ${ }^{57}$, Robert Denhardt i Janet Denhardt ${ }^{58}$ oraz Jennifer Stewart i Paul Kringas ${ }^{59}$. Pozostałe dwa czynniki, które - według ankietowanych są mało istotne - wskazywane są w literaturze również jako czynniki sukcesu, ale nie tak często jak wsparcie polityczne dla zmian. W przypadku wprowadzania „agenta zamian” niska ocena tego czynnika może wynikać z niewystępowania takiego stanowiska w praktyce zarządzania w badanej instytucji. Jest to jedyny czynnik, który nie został uznany za bardzo istotny. Oceniając niskie znaczenie ograniczenia kontroli biurokratycznych we wprowadzaniu zmian, pracownicy mogli brać pod uwagę fakt, że biurokracja jest permanentnym czynnikiem towarzyszącym ich pracy i jako taka nie ma większego wpływu na wprowadzanie zmian organizacyjnych. W przypadku czynników uznanych za bardzo istotne (odpowiedzi 4 i 5), respondenci wskazali trzy obszary. Należą do nich: zmotywowanie pracowników do zmian (100\% wskazań na ocenę 4 lub 5), posiadanie wystarczających zasobów (100\% wskazań) oraz komunikacja w organizacji (100\% wskazań). Przy czym dwa pierwsze z nich otrzymały aż 72,5\% wskazań, że są bardzo istotne we wdrażaniu zmian. Na posiadanie odpowiednich zasobów we wdrażaniu zmian wskazywał w swych badaniach W.J. Kikert ${ }^{60}$ oraz R. Denhardt i J. Denhardt ${ }^{61}$. Podkreślają oni swoich badaniach, że bez odpowiednich zasobów wdrożenie zmian powoduje wyższy poziom stresu interpersonalnego oraz zaniedbanie

\footnotetext{
${ }^{57}$ W.J. Kickert, dz. cyt., s. 693-717.

${ }^{58}$ R.B. Denhardt, J.V. Denhardt, dz. cyt.

59 J. Stewart, P. Kringas, dz. cyt., s. 686.

${ }^{60}$ W.J. Kickert, dz. cyt., s. 693-717.

${ }^{61}$ R.B. Denhardt, J.V. Denhardt, dz. cyt.
} 
podstawowych działań w organizacji. Według D. Baker pozostałe dwa czynniki uznane za bardzo istotne związane są z umiejętnościami liderów organizacji ${ }^{62}$.

\section{Podsumowanie}

Poznanie czynników decydujących o sukcesie zmian w organizacjach publicznych, jest zagadnieniem, które warto podjąć, aby lepiej zrozumieć, w jaki sposób można skutecznie zarządzać podmiotami sektora publicznego. Jak wynika z analizy, samo przekonanie członków organizacji o potrzebie zmian jest niewystarczające, aby spowodować zmianę. Menedżerowie publiczni powinni podejmować decyzje w różnych obszarach funkcjonowania organizacji, aby zmiany zostały wprowadzane skutecznie. $\mathrm{Z}$ analizy literatury zawierającej badania z obszaru zarządzania zmianą w organizacjach publicznych oraz z przeprowadzonych analiz w agencji wdrażającej politykę rolną wynika, że można zidentyfikować czynniki, które są najczęściej wskazywane jako te, które pozwalają osiągnąć sukces. Można zaliczyć do nich: ustanowienie poczucia pilności (potrzeby) zmian (znalezienie właściwej równowagi między ryzykiem a sensem wprowadzania zmian); opracowanie planu wprowadzenia zmian (wizji, strategii); opracowanie modelu wprowadzenia zmian; komunikacja w organizacji; posiadanie wystarczających zasobów; silne przywództwo lidera; zmotywowanie pracowników do zmian (zapewnienie, żeby pracownicy czuli się zaangażowani, zintegrowani i wartościowi); zakotwiczenie wyniku zmian w kulturze organizacyjnej; posiadanie wsparcia politycznego do zmian; wprowadzenie agenta zmian; wprowadzanie innowacyjnej i zdigitalizowanej technologii oraz uwolnienie procedur i ograniczenie kontroli biurokratycznych.

Uzyskane wyniki mogą stanowić wskazówki dla menadżerów w badanej instytucji, na jakie czynniki należy zwrócić uwagę w pierwszej

${ }^{62}$ D. Baker, dz. cyt., s. 243. 
kolejności. Warto jednak pamiętać, że pracownicy w organizacji opierają się zmianom z różnych powodów, np. zmiany są źle pomyślane, nieuzasadnione lub mogą doprowadzić do negatywnych konsekwencji dla członków organizacji. Dlatego też, istotne jest prowadzenie badań empirycznych w polskich organizacjach publicznych w obszarze czynników decydujących o sukcesie wprowadzania zmian oraz nad procesem ich przebiegu. Przeprowadzone studia nad literaturą przedmiotu obarczone są ograniczeniami wynikającymi z wyboru artykułów do analizy, jak również z ograniczonymi wynikami badań publikowanymi w zakresie zarządzania zmianą w organizacjach sektora publicznego. W przypadku badań empirycznych za podstawowe ograniczenie należy uznać niereprezentatywność badanej próby. Uzyskane wyniki mogą stanowić podstawę dalszych analiz w organizacjach publicznych w obszarze zarządzania zmianami. 